\title{
Performance of rainwater harvesting system based on roof catchment area and storage tank capacity
}

\author{
Imroatul C. Juliana ${ }^{1}$, M. Syahril Badri Kusuma ${ }^{2}$, M. Cahyono ${ }^{2}$, Hadi Kardhana ${ }^{3}$, and Widjaja Martokusumo ${ }^{4}$ \\ ${ }^{1}$ Faculty of Civil and Environmental Engineering, Bandung Institute of Technology, Indonesia \\ ${ }^{2}$ Water Resources Development Center, Bandung Institute of Technology, Indonesia \\ ${ }^{3}$ Center for Research on Infrastructure and Regional, Bandung Institute of Technology, Indonesia \\ ${ }^{4}$ School of Architecture, Planning, and Development Policy, Bandung Institute of Technology, Indonesia
}

\begin{abstract}
Increasing population growth has created problems in water resources. Natural water resources become progressively more expensive and difficult to develop. In addition, it is also becoming increasingly polluted and difficult to obtain. Many countries shown a resurgent interest in the use of rainwater harvesting (RWH) technique to overcome these problems. There are several factors that will influence the RWH performance, such as the rainfall, catchment area, storage tank capacity, and water demand. The performance parameter determines by the volumetric reliability, time reliability, and yield. The RWH system used in this study is a simple RWH system that utilizes roof as a catchment area, pipes as a distribution system and tank as a storage. An analysis is carried out to investigate the effect of altering the large of the catchment area and storage tank capacity to the RWH system performance parameters. A suitable behavioral model based on the water balance method is implemented to evaluate the inflow, outflow, and the storage volume. Results demonstrate that with up to 15 years daily rainfall data in 15 cities in Indonesia, the most influential parameters on the performance of RWH system is the time reliability.
\end{abstract}

\section{Introduction}

Human population growth for the last few decades has increased exponentially. Increasing human population growth lead to the emergence problems in the water resources either directly or indirectly. In terms of quality or quantity, the usefulness of water will reduce, and water damage will be even greater. Furthermore, the problem of water resources becomes complicated as the lack of management of water resources. Accordingly, if the water resources optimally use and manage, such problems can be avoided.

Rainwater is one of the potential water resources that is often overlooked. The potential rainfall-yet- unused rainwater often thrown out into a run-off. Whereas the rainwater can be collected and afterward processes in raw water that is ready to use [1].

Rainwater harvesting is a simple ancient technology and can vary from minor and basic to major and complex. Previous studies have shown that the consumption of rainwater provides economic and environmental benefits. Rainwater that has been collected can be used for nonpotable water use, thereby it could reduce the consumption of groundwater and provide financial benefits [2].

Similar studies corroborate that the rainwater harvesting system also provides the advantage from an economic standpoint [3-9]. The rainwater harvesting concept also bestows significant impact on the surrounding environment [10]. The usage of rainwater harvesting system on a large scale is taken into consideration as an adaptive strategy in dealing with climate change, related to water shortages [11].

The use of rainwater harvesting system (RWH) had declined in many developed countries including Indonesia. There are several factors that contribute to that e.g. the public perception on the installation of RWH system is expensive and does not provide significant benefit in terms of economic or environmental. Therefore, there should be a study comprehensively on the RWH system performance in order to analyze the feasibility of the system implementation. Several parameters, such as the volumetric reliability, time reliability and yield could define the RWH system performance.

This study aims to investigate the contribution of the roof catchment area and storage tank capacities to the alteration of RWH system performance parameters. Thus, it can analyze which performance parameter is the most affected. This would be outstandingly beneficial for the design of the RWH system.

\section{Methodology}

This study uses a simple RWH system that used the roof as a catchment area, pipes as a distribution system and tank as a storage. The storage tank capacity is a vital component as it will determine the entire system performance and cost.

The characteristic of the catchment area, potential rainfall, and water demand will contribute to the RWH system performance [1]. The daily rainfall data from 29 
rainfall stations in 15 cities in Indonesia from Sumatera to Sulawesi were used. The length of the data is varying from 7 years to 15 years, according to the data availability. The cities were divided into 4 categories according to the annual rainfall range.

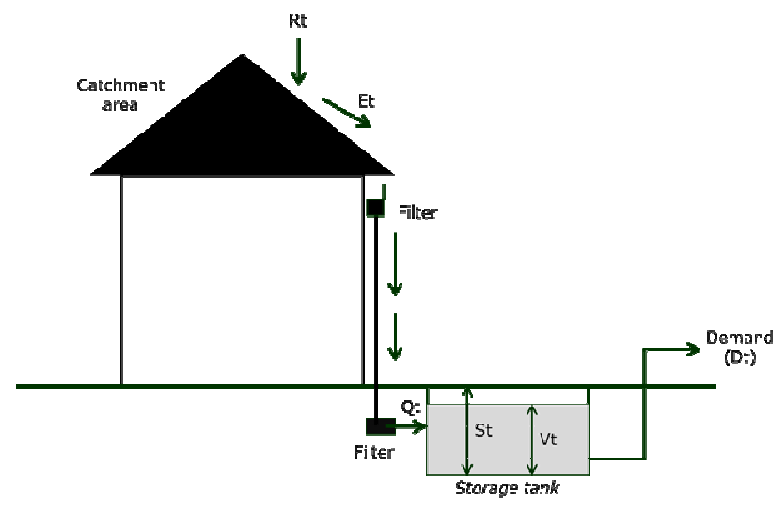

Adapted : Roebuck, 2010

Fig. 1. Schematic representation of the simple rainwater harvesting system

The effective rainfall volume obtains by multiplying the rainfall with the catchment area and runoff coefficient.

$$
E R=R_{t} . A . C
$$

Where ER is the effective runoff $\left(\mathrm{m}^{3}\right), \mathrm{R}_{\mathrm{t}}$ is daily rainfall $(\mathrm{mm}), A$ is catchment area wide $\left(\mathrm{m}^{2}\right)$ and $C$ is the ratio of the rainwater that could be caught in the catchment area.

The water balance method is used to describe the simulation of the system. The yield before spillage (YBS) algorithm used to describe the storage tank behavior.

$$
V_{t}=V_{t-1}+Q_{t}-D_{t}-E_{t}-L_{t}
$$

$\mathrm{V}_{\mathrm{t}}$ is storage volume at time $\mathrm{t}\left(\mathrm{m}^{3}\right), \mathrm{V}_{\mathrm{t}-1}$ is the storage volume at time $t-1\left(\mathrm{~m}^{3}\right), \mathrm{Q}_{\mathrm{t}}$ is the volume that enters the storage in a time interval $\mathrm{t}\left(\mathrm{m}^{3}\right), \mathrm{D}_{\mathrm{t}}$ is a demand release in lapse of time $t\left(\mathrm{~m}^{3}\right), \mathrm{E}_{\mathrm{t}}$ is evaporation $(\mathrm{mm}), \mathrm{L}_{\mathrm{t}}$ is the losses $(\mathrm{mm})$ and $\mathrm{S}$ is the storage capacity $\left(\mathrm{m}^{3}\right)$. In this study, the effect of evaporation and losses is disregarded since the storage tank is below ground, so that:

$$
V_{t}=V_{t-1}+Q_{t}-D_{t}
$$

where $0 \leq V_{t} \leq S$

The RWH system performance expressed with the reliability parameter. The units of volume and time could express the reliability of the storage tank capacity [12]. Liaw and Tsai defined volumetric reliability as the total volume of harvested rainwater supplied divided by the total water demand (VR) and time reliability is the fraction of time that demand is fully met divided by total time under consideration (TR) [13].

$$
\mathrm{VR}=\frac{\sum_{\mathrm{t}=1}^{\mathrm{T}} \mathrm{Y}_{\mathrm{t}}}{\sum_{\mathrm{t}=1}^{\mathrm{T}} \mathrm{D}_{\mathrm{t}}} \times 100
$$

$$
\mathrm{TR}=\frac{\sum_{\mathrm{t}=1}^{\mathrm{T}} \mathrm{YT}_{\mathrm{t}}}{\sum_{\mathrm{t}=1}^{\mathrm{T}} \mathrm{T}_{\mathrm{t}}} \times 100
$$

where VR is the volumetric reliability, TR is the time reliability, $Y_{t}$ is yield in time $t\left(\mathrm{~m}^{3}\right), D_{t}$ is total demand in time $t$ period $\left(\mathrm{m}^{3}\right), \mathrm{YT}_{\mathrm{t}}$ is the total days that the water need fulfill with RWH (days), and $T_{t}$ is total time under consideration (days).

The sensitivity analysis carried out in order to determine the level of variation in predicting $\mathrm{RWH}$ system performance to changes in the catchment area and storage tank capacities. The alteration in the catchment area and storage tank capacity defined by:

$$
\begin{gathered}
\mathrm{C}_{\mathrm{c}}=\frac{\mathrm{CA}_{\mathrm{n}}-\mathrm{CA}_{\mathrm{b}}}{\mathrm{CA}_{\mathrm{b}}} \times 100 \% \\
\mathrm{~S}_{\mathrm{c}}=\frac{\mathrm{S}_{\mathrm{n}}-\mathrm{S}_{\mathrm{b}}}{\mathrm{S}_{\mathrm{b}}} \times 100 \%
\end{gathered}
$$

where $C_{c}$ is the alteration of the catchment area, $\mathrm{CA}_{n}$ is the catchment area at $n, C A_{b}$ is the benchmark of the catchment area, $S_{c}$ is the alteration of storage tank, $S_{n}$ is the storage tank at point $\mathrm{n}, \mathrm{S}_{\mathrm{b}}$ is the benchmark of the storage tank.

Percentage changes in RWH system performance, such as VR, TR and yield were selected as the metric for judging the sensitivity. By performing this analysis, the possible consequences of such changes can be evaluated. Sensitivity analysis performed for two conditions variation : the large of the catchment area and the storage tank capacity. The graph gradient will show the extremely affected parameter. The steepest gradient generates, the greater the effect of these parameters on the RWH system performance.

\section{Results and analysis}

\subsection{Analysis on the roof catchment area alteration}

The analysis conducted on alteration of the roof catchment area from $10 \mathrm{~m}^{2}$ to $1200 \mathrm{~m}^{2}$. The $70 \mathrm{~m}^{2}$ catchment area and $2 \mathrm{~m}^{3}$ storage tank capacity are set as a base case result. The water uses divided into all water use and nonpotable water use. A constant occupancy of 1 occupant with total water use is $150 \mathrm{~L} /$ person/day [14, 15]. Two storage tank capacities : $2 \mathrm{~m}^{3}$ and $5 \mathrm{~m}^{3}$ was assumed. The results of the sensitivity analysis are in the following graphs. In each case, the results from all rainfall ranges were plotted on the same chart to make direct comparisons easier. 


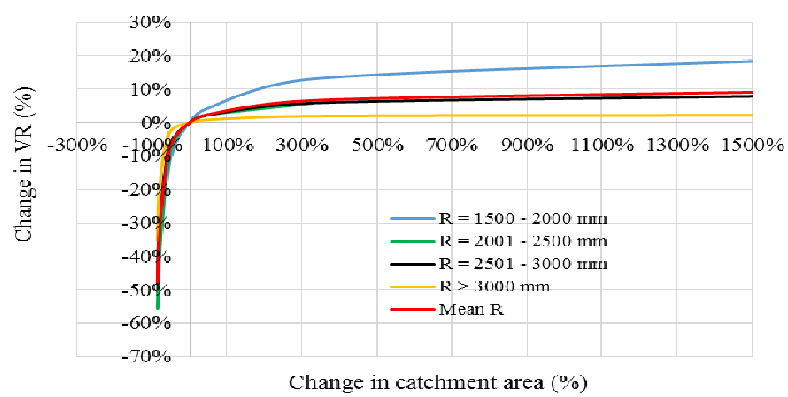

(a) $\operatorname{tank} 2 \mathrm{~m}^{3}$ - all water use

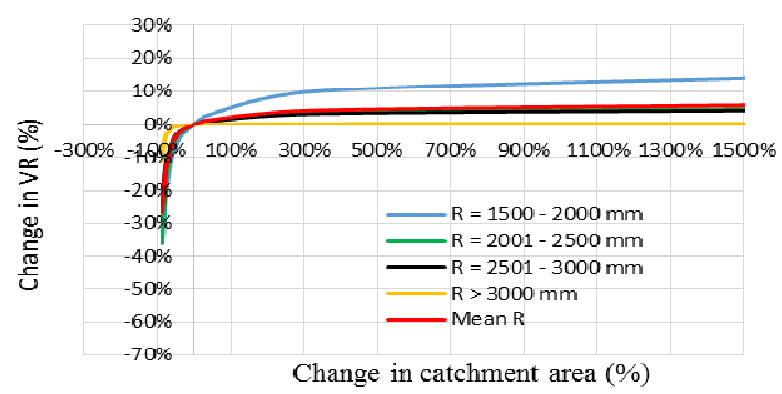

(b) tank $2 \mathrm{~m}^{3}$ - nonportable water use

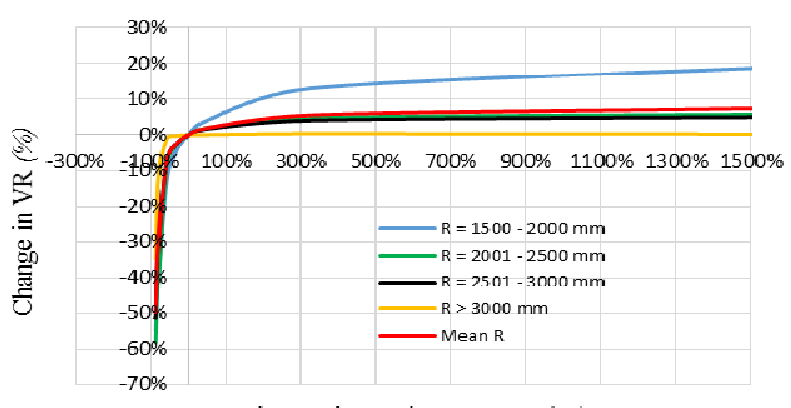

Change in catchment area (\%)

(c) $\operatorname{tank} 5 \mathrm{~m}^{3}$ - all water use

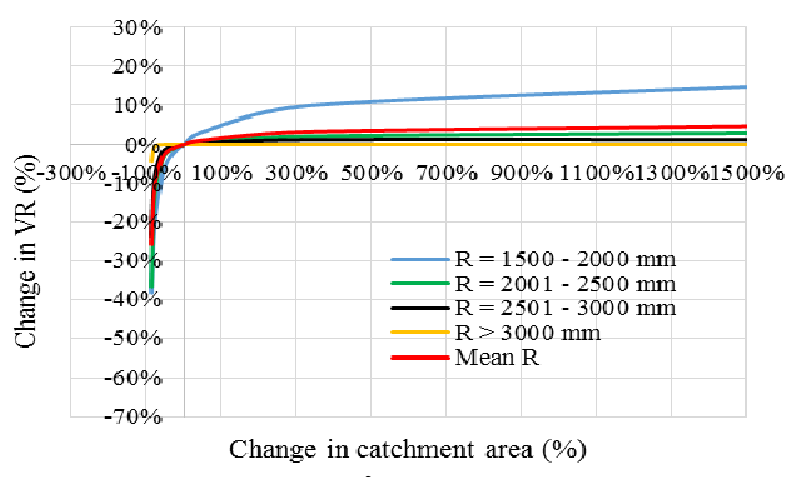

(d) tank $5 \mathrm{~m}^{3}$ - nonportable water use

Fig. 2. Sensitivity to alteration in catchment area of volumetric reliability (VR)

Figures 2 to 4 , shows the average differences between the results for eight catchment areas. Each tank displayed similar trends with regards to the influence of the catchment area and water uses. Analysis of the results showed that there is a nonlinear relationship between the increasing in the catchment area with the system performance and annual yield. Furthermore, there is a positive gradient indicating that the increased in the catchment area would lead to an increase in system performance.

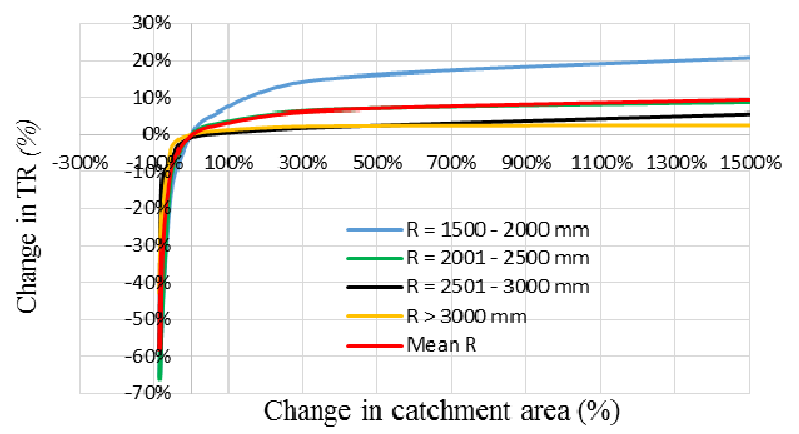

(a) $\operatorname{tank} 2 \mathrm{~m}^{3}-$ all water use

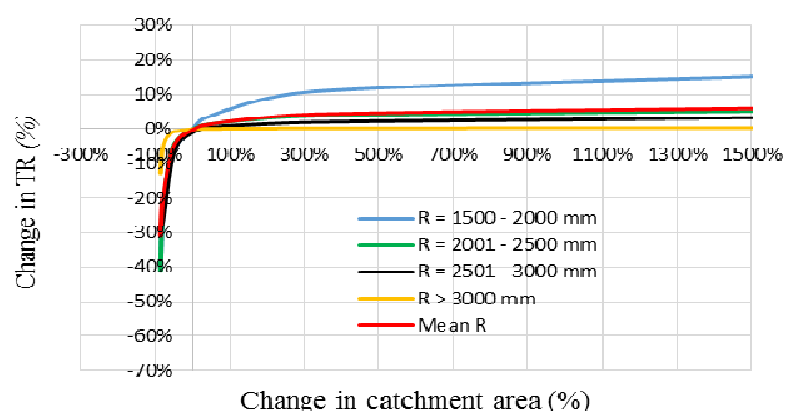

(b) tank $2 \mathrm{~m}^{3}$ - nonpotable water use

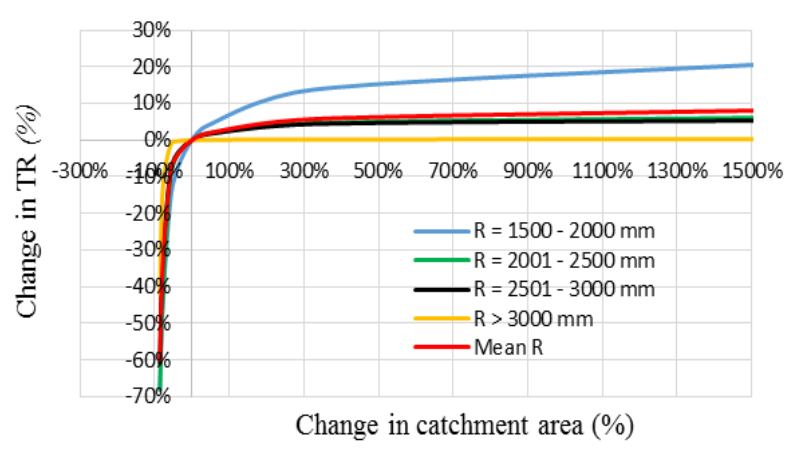

(c) $\operatorname{tank} 5 \mathrm{~m}^{3}$ - all water use

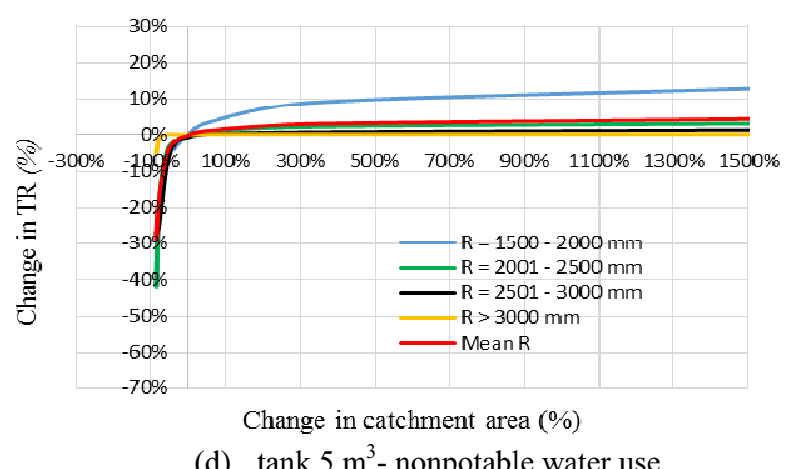

Fig. 3. Sensitivity to alteration in catchment area of timemetric reliability (TR) 


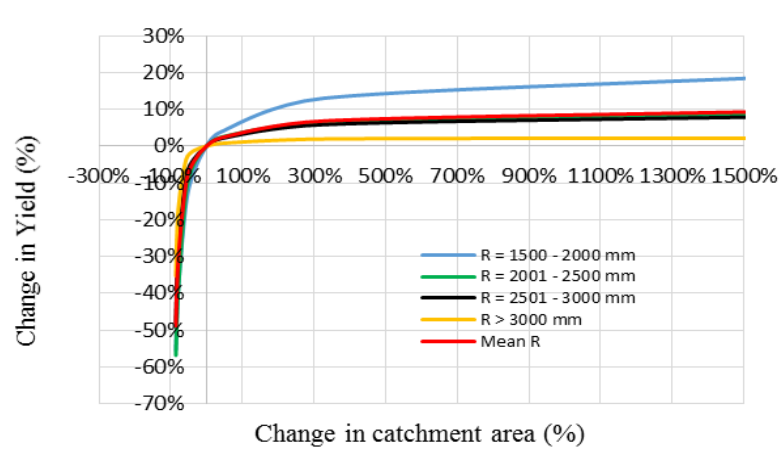

(a) $\operatorname{tank} 2 \mathrm{~m}^{3}$ - all water use

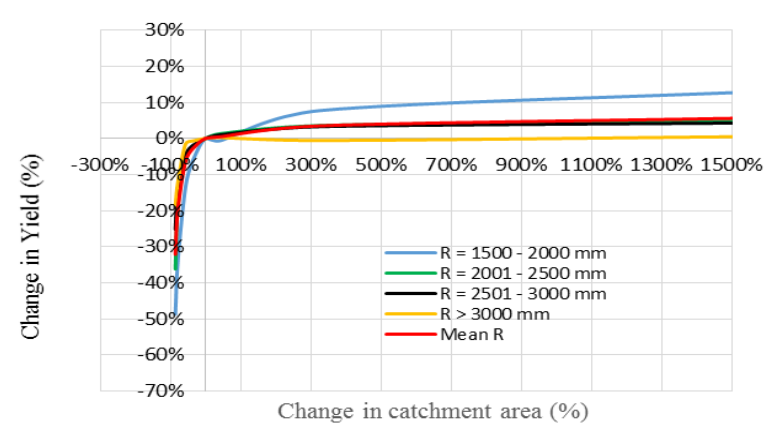

(b) tank $2 \mathrm{~m}^{3}$ - nonpotable water use

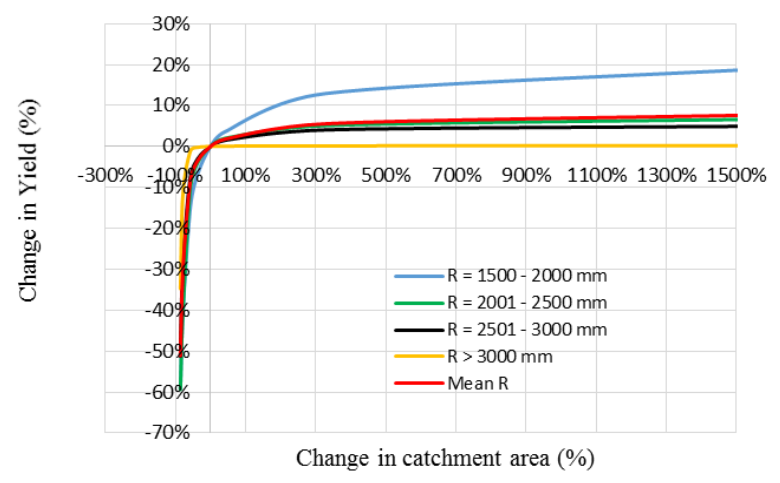

(c) $\operatorname{tank} 5 \mathrm{~m}^{3}$ - all water use

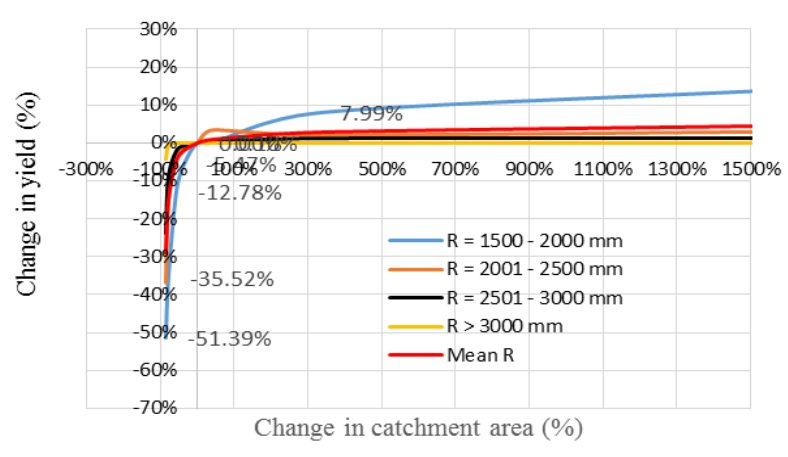

(d) $\operatorname{tank} 5 \mathrm{~m}^{3}$ - nonpotable water use

Fig. 4. Sensitivity to alteration in catchment area of yield

The gradient of the graph progressively ramps, especially in the wide of catchment area over $300 \mathrm{~m}^{2}$. The rate of graphs gradient increasingly sharps for the catchment area less than $70 \mathrm{~m}^{2}$. Therefore, this indicates that the increase in the catchment area below $70 \mathrm{~m}^{2}$ extremely influential on the performance of RWH systems.
Rainfall also affects system performance. The lesser the annual rainfall, the increase of the catchment area gives the extra impact on the system performance and vice versa. Moreover, the increase in the catchment area is influential for annual rainfall $1500 \mathrm{~mm} \mathrm{-} 2000$ $\mathrm{mm} /$ year. For annual precipitation above $3000 \mathrm{~mm} /$ year, the rate of changes was relatively small, especially for the catchment area above $70 \mathrm{~m}^{2}$.

Table 1. The graph gradient for each parameter to alteration in the catchment area

\begin{tabular}{|c|c|c|c|c|c|c|}
\hline \multirow{2}{*}{\begin{tabular}{c} 
Catchment $\begin{array}{c}\text { area } \\
\left(\mathrm{m}^{2}\right)\end{array}$ \\
\cline { 2 - 7 }
\end{tabular}} & \multicolumn{2}{|c|}{$\begin{array}{c}\text { Mean VR } \\
\text { gradient }\end{array}$} & \multicolumn{2}{c|}{$\begin{array}{c}\text { Mean TR } \\
\text { gradient }\end{array}$} & \multicolumn{2}{c|}{$\begin{array}{c}\text { Mean yield } \\
\text { gradient }\end{array}$} \\
\hline 10 & 0.44 & 0.44 & 0.52 & 0.52 & 0.47 & 0.47 \\
\hline 15 & 0.27 & 0.26 & 0.31 & 0.32 & 0.32 & 0.29 \\
\hline 30 & 0.11 & 0.10 & 0.15 & 0.12 & 0.14 & 0.11 \\
\hline 45 & 0.07 & 0.06 & 0.10 & 0.07 & 0.10 & 0.07 \\
\hline $\mathbf{5} \mathbf{m}^{\mathbf{3}}$ & $\mathbf{2} \mathbf{~ m}^{\mathbf{3}}$ & $\begin{array}{c}\mathbf{5} \\
\mathbf{m}^{\mathbf{3}}\end{array}$ \\
\hline $\mathbf{7 0}$ & \multicolumn{6}{|c|}{ Bench mark } \\
\hline 100 & 0.04 & 0.03 & 0.04 & 0.03 & 0.03 & 0.03 \\
\hline 300 & 0.01 & 0.01 & 0.02 & 0.01 & 0.02 & 0.01 \\
\hline 1200 & 0.00 & 0.00 & 0.00 & 0.00 & 0.00 & 0.00 \\
\hline
\end{tabular}

Table 1 shows the graph gradient for each parameter. The gradient of $2 \mathrm{~m}^{3}$ and $5 \mathrm{~m}^{3}$ storage tank capacity in each parameter approximately the same particularly for the larger catchment area. From the results, it can be concluded that the most affected parameter by the alteration in catchment area is the time reliability parameter. Despite the differences tend to be diminutive, not more than a few percentage. As a result, the differences from each parameter are not further than $50 \%$. Therefore, the alteration in storage tank capacity also does not perform a significant increase in system performance. The larger the catchment area, the alteration in parameter is close to (zero).

\subsection{Analysis on the alteration of storage tank capacity}

The analysis conducted under 4 storage tank capacities alteration, which are $1 \mathrm{~m}^{3}, 2 \mathrm{~m}^{3}, 5 \mathrm{~m}^{3}$, and $10 \mathrm{~m}^{3}$. The 2 $\mathrm{m}^{3}$ storage tank capacity assumed as a benchmark. The water uses divided into all water use and nonpotable water use for 1 occupant. The catchment area is defined as $70 \mathrm{~m}^{2}$. The sensitivity on the alteration of storage tank capacity can be seen in figure 5 to 7 .

Figure 5 to 7 , shows the effects of varying annual rainfall on the RWH system performance. A range of water uses and storage tank capacity were used in order to cover a wide range of possible scenarios. From the graphs, the lesser the rainfall, there is a linear relation between the upsurge in storage tank capacity and the system performance. For storage tank capacity below 2 $\mathrm{m}^{3}$, the relations tend to be nonlinear with fairly steep gradient, conversely, compared with storage tank capacities above $2 \mathrm{~m}^{3}$. 


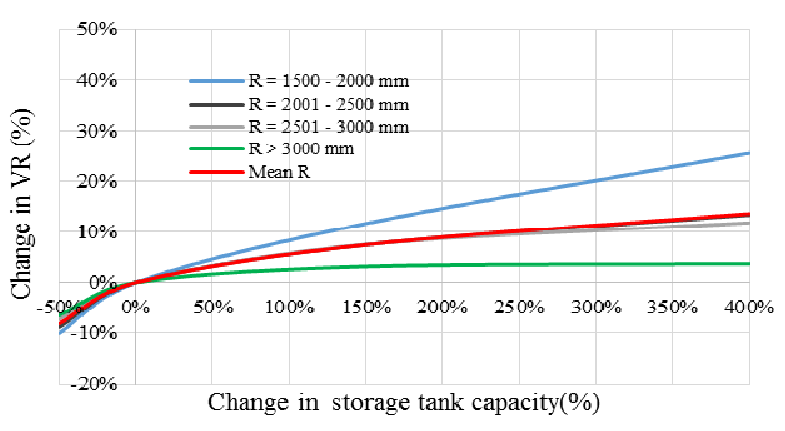

(a) all water use

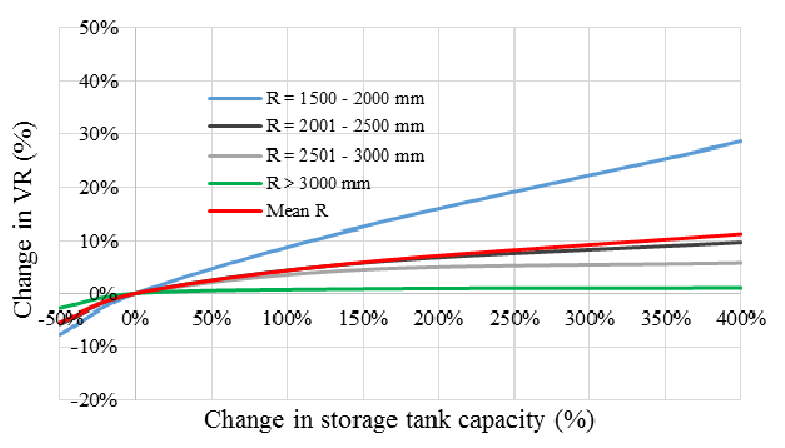

(b) nonpotable water use

Fig. 5. Sensitivity to alteration in storage tank capacity of volumetric reliability (VR)

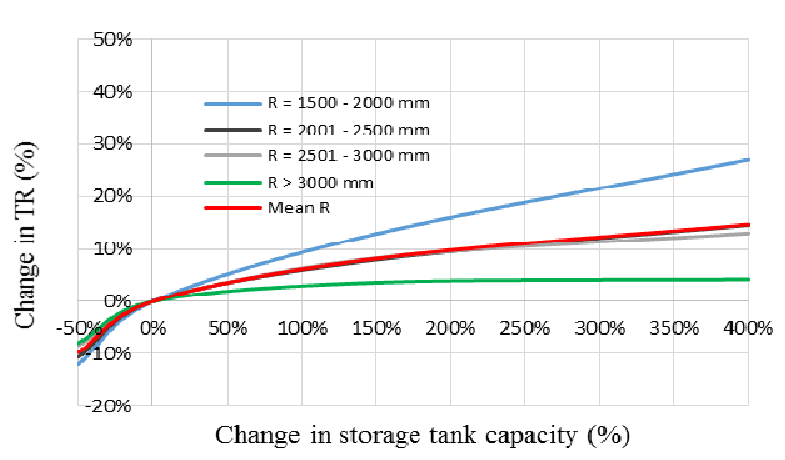

(a) all water use

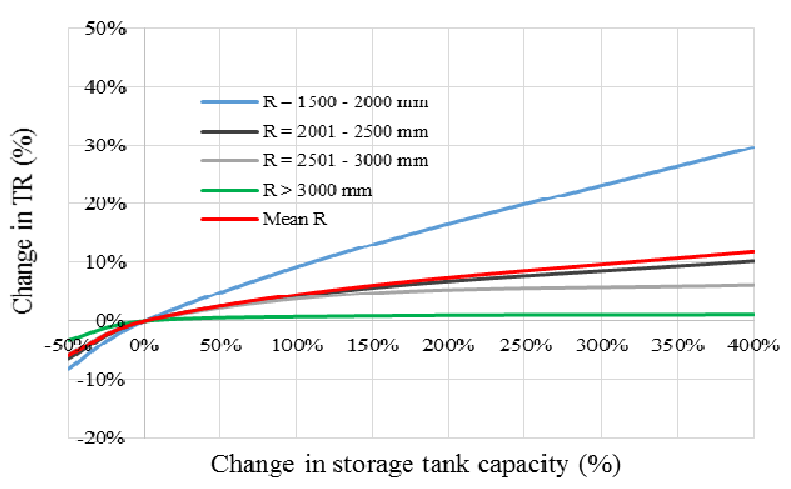

(b) nonpotable water use

Fig. 6. Sensitivity to alteration in storage tank capacity of time reliability (TR)

The graph gradient is positive which indicates that the increase in storage tank capacity will lead to the increase of the system performance. Ordinarily, the larger the rainfall, the gradient becoming declivous. Especially for the rainfall above $3000 \mathrm{~mm} /$ year, the increase in storage tank capacity will not significantly affect the system performance. However, the increase in storage tank capacity will deliver the vast effect for a rainfall with a range $1500 \mathrm{~mm} /$ year - $2000 \mathrm{~mm} /$ year. This matter can be seen from the sharp gradient and far enough span with the annual rainfall 2001 - 3000 $\mathrm{mm} /$ year. The increase of RWH system performance is almost equal for annual rainfall of $2000-2500 \mathrm{~mm} /$ year and 2501- $3000 \mathrm{~mm} /$ year. It is perceived from the merging gradient lines between the two ranges primarily for the more water use.

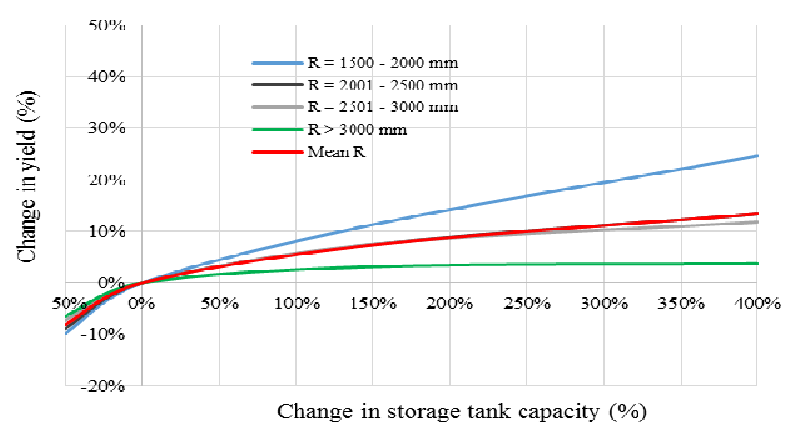

(a) all water use

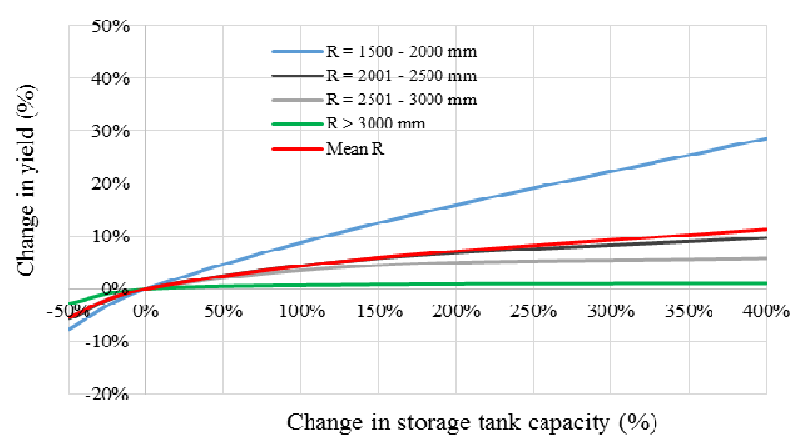

(b) nonpotable water use

Fig. 7. Sensitivity to alteration in storage tank capacity of yield

Table 2. The graph gradient for each parameter to alteration in storage tank capacities

\begin{tabular}{|c|c|c|c|}
\hline $\begin{array}{c}\text { Storage tank } \\
\left.\text { capacity } \mathbf{( m}^{\mathbf{3}}\right)\end{array}$ & $\begin{array}{c}\text { Mean VR } \\
\text { gradient }\end{array}$ & $\begin{array}{c}\text { Mean TR } \\
\text { gradient }\end{array}$ & $\begin{array}{c}\text { Mean yield } \\
\text { gradient }\end{array}$ \\
\hline 1 & 0.135 & 0.156 & 0.134 \\
\hline 2 & \multicolumn{3}{|c|}{ Benchmark } \\
\hline 5 & 0.045 & 0.048 & 0.044 \\
\hline 10 & 0.031 & 0.033 & 0.031 \\
\hline
\end{tabular}

Table 2 shows the graph gradient associated with each of the key parameters. The gradient of VR, TR and yield for each storage tank capacity are approximately the same particularly for the bigger storage tank capacity. From the results, it can be concluded that the most sensitive parameter by the alteration in storage tank capacity increase is the time reliability parameter. Therefore, the alteration in storage tank capacity also does not perform a significant increase in system performance. Whilst, the performance for up to $5 \mathrm{~m}^{3}$ 
storage tank capacity is decreased. This indicated that the saturation point of storage tank capacity for the range of rainfall is $5 \mathrm{~m}^{3}$.

\section{Conclusions}

The predicted RWH system performances depend overwhelmingly on the annual rainfall, storage tank capacity, and catchment area. From the analysis, it can be concluded that the most sensitive parameter within the alteration in the catchment area and storage tank capacity is the time reliability even though the difference with the other parameters is insignificant. The graphs also demonstrate that the smallest annual rainfall encounters the biggest influence of the alteration.

The authors would like to express the highest gratitude to Engineering Faculty, Sriwijaya University for the initial funding for this research. Our sincere thanks go to Water Resources Development Center, Center for Research on Infrastructure and Regional, Bandung Institute of Technology, for its supports during this publication process. The authors would also like to gratefully the BMKG Online for providing the secondary data.

\section{References}

1. Frasier, Gary, Myers, The Handbook Of Water Harvesting, US Department of Agriculture, Washington DC, (1983)

2. R.M. Roebuck, Ashley, Proceeding 7th International Conference of Urban Drainage Modelling, (2006)

3. Yan Zhang, Donghui Chen, L. Chen, L., S. Ashbolt, Journal of Environmental Management 91, p : 222226, (2009)

4. Vivian Tam, Zeng S.X., Journal of Resources, Conservation and Recycling 54, p : 178-186, (2010)
5. Anthony M. Ryan, Clive Spash, Thomas G. Measham, Journal of Hydrology 379, p : 164-171, (2009)

6. A. Rahman, J. Dbais, M. Imteaz, American Journal of Engineering and Applied Sciences 3 (1), p : 73$82,(2010)$

7. Ataur Rahman, Joseph K, M. Imteaz, Journal of Resources, Conservation and Recycling 61, p : 1621, (2012)

8. R. Farreny, X. Gabarrell, J. Rieradevall, Journal of Resources, Conservation and Recycling 55, Netherlands, p : 686-694, (2011)

9. N. Nagaraj, U. Pradhani, U., Chengappa, Agricultural Economics Research Review 24, India, p : 217-223, (2011)

10. Sara Angrill, Farreny, Ramon, Gasol, International Journal of Life Cycle Assess, DOI 10.1007/s11367011-0330-6, (2011)

11. K. E. Trenberth, P.D. Jones, P. Ambenje, R. Bojariu, D. Easterling, A. Klein Tank, D. Parker, F. Rahimzadeh, J.A. Renwick, M. Rusticucci, B. Soden, and P. Zhai, Observations: Surface and atmospheric climate change. Cambridge University Press, Cambridge, (2007)

12. A. Fewkes, D. Butler, Proceedings of the $9^{\text {th }}$ International Rainwater Catchment Systems Conference, (1999)

13. C. Liaw, Y. Tsai, Journal of the American Water Resources Association 40 no. 4, p : 901-912, (2004)

14. Dian Mangiring, Kajian Pola Konsumsi Air Bersih Rumah Tangga di Kelurahan Setiamanah Kota Cimahi sebagai Masukan Bagi Upaya Konservasi, Master Thesis, ITB, Bandung, (2007)

15. Direktorat Penataan Bangunan dan Lingkungan, Peraturan Perunandg-unandgan Bidang Bangunan Gedung and Lingkungan, Kementrian Pekerjaan Umum, Direktorat Jenderal Cipta Karya, (2010) 